\title{
Total electrolyte balance for laying hens
}

\section{Vitor Colossal da Silva ${ }^{*}$ (D) Wagner Azis Garcia de Araújo ${ }^{1(D)}$ Jean Kaique Valentim $^{2}$ (D) Hébert Fernandes de Brito ${ }^{1}$ Hérica da Silva Messias ${ }^{1}$ Br $^{-}$Bruna Pereira Siqueira ${ }^{1}$ Bruno Alexander Nunes Silva ${ }^{3}$ Dielly Inêz Oliveira Lacerda ${ }^{4}$ id}

${ }^{1}$ Programa de Pós-graduação em Medicina Veterinária, Instituto Federal de Educação, Ciência e Tecnologia do Norte de Minas Gerais (IFNMG), 39560-000, Salinas, MG, Brasil. E-mail: vitorcolossal@outlook.com. "Corresponding author.

${ }^{2}$ Programa de Pós-graduação em Zootecnia, Universidade Federal da Grande Dourados (UFGD), Dourados, MS, Brasil.

${ }^{3}$ Programa de Pós-graduação em Produção Animal, Universidade Federal de Minas Gerais (UFMG), Montes Claros, MG, Brasil.

${ }^{4}$ Programa de Pós-graduação em Zootecnia, Universidade Estadual de Montes Claros (Unimontes), Montes Claros, MG, Brasil.

ABSTRACT: This study was done to determine the best value of the total electrolyte balance (BET) concerning the variables of performance and egg quality of the laying hens. We investigated $240 \mathrm{Hy}$-Line Brown laying hens, of 30 to 46 weeks of age, adopting the completely randomized experimental design, which included five treatments (1000, 1250, 1500, 1750 and $2000 \mu \mathrm{eq} / \mathrm{kg}), 8$ repetitions and 6 birds per unit. The performance and quality of the birds' eggs were evaluated in the different treatments. The results were subjected to the analysis of variance and, wherever significant effect was noted, the regression equations were estimated, taking into account the electrolyte balance ( $\mu$ eq $/ \mathrm{kg}$ ) as a concomitant variable, applying the SAS statistical program (2001). The consumption, production, and feed conversion variables by dozen eggs, final bird weight, egg density, yolk color, Haugh Unit, albumen weight, shell weight, and egg weight, were found to be unaffected by the experimental BET values. The values of the feed conversion per egg mass, yolk weight and uniformity were affected by the different BETs. The electrolyte balance values showing minimum feed conversion, higher yolk weight, and better uniformity were, respectively, BET $=1400$, 1330, and $1250 \mathrm{in} \mu \mathrm{eq} / \mathrm{kg}$ of loads at the different temperatures. From the regression equations, the value indicated was BET=1390 for the 30- to 46-week-old laying hens. The electrolyte balance of the diet was found to affect the laying hens in terms of performance and egg quality. Key words: electrolytes, avian physiology, egg formation, commercial feed.

Balanço eletrolítico total para galinhas poedeiras

RESUMO: Objetivou-se avaliar o melhor valor de balanço eletrolitico total (BET) para as variáveis de desempenho e qualidade dos ovos de galinhas poedeiras. Foram utilizadas 240 galinhas poedeiras da linhagem HyLine Brown, durante o período de 30 a 46 semanas de idade, distribuídos em um delineamento inteiramente casualizado, com cinco tratamentos (1000, 1250, 1500, 1750 e $2000 \mu \mathrm{eq} / \mathrm{kg})$, oito repetições e seis aves por unidade experimental. Foram avaliados o desempenho e a qualidade dos ovos das aves com os diferentes tratamentos. Foi realizada análise de variância e, no caso de efeito significativo, foram estimadas equações de regressão considerando como variável concomitante o balanço eletrolitico ( $\mu \mathrm{eq} / \mathrm{kg}$ ), usando o programa estatístico SAS (2001). As variáveis de consumo, produção, conversão alimentar por dúzia de ovos, peso final das aves, densidade do ovo, coloração da gema, Unidade Haugh, peso do albúmen, peso da casca e peso do ovo, não foram afetados pelos BET experimentais. Os valores de conversão alimentar por massa de ovos, peso de gema e uniformidade foram influenciados pelos diferentes BET. Os valores de balanço eletrolítico que propiciaram conversão alimentar mínima, melhor peso de gema e melhor uniformidade foram, respectivamente: BET=1400, BET =1330 e BET = 1250 em $\mu \mathrm{eq} / \mathrm{kg}$ de cargas nas rações. Conforme as equações de regressão indica-se o valor de BET de 1390 para poedeiras de 30 a 46 semanas de idade. O balanço eletrolítico da dieta afeta o desempenho e a qualidade dos ovos de galinhas poedeiras.

Palavras-chave: eletrólitos, fisiologia aviária, formação do ovo, rações comerciais.

\section{INTRODUCTION}

In the hens, the maintenance of the acidbase balance was found to exert a strong influence on the physiological and biochemical aspects which, in turn, could affect the metabolic processes related to growth, disease resistance, survival under stress and animal performance (BRETÂS et al., 2010). MORAES et al., (2019) reported that sodium, potassium, and chloride were fundamental to the maintenance of osmotic pressure and the acid-base balance of the body fluids. 
The electrolytes present in the birdfeed were observed to alter the acid-base balance and, thus affect the metabolic processes concerned with growth, production, health, stress, and well-being (WANG et al., 2020).

This balance is linked to the electrolyte intake by the hens. The total electrolyte balance (BET) can affect growth, consumption, bone development, thermal stress, and cellular and osmotic metabolism (PATIENCE, 1990). Therefore, to avert acid-base imbalance, the rations needed to be supplemented with electrolytes like sodium bicarbonate and potassium chloride, which have been employed in the warm climate zones. The present diet contains many ingredients that can affect the electrolyte balance (BE); however, these are excluded in the model proposed by Mongin (1981), for example, the synthetic amino acids.

It was ARAÚJO et al., (2011) who proposed a new method of determining the electrolyte balance where these electrolytes were counted as the total electrolyte balance (BET). As the knowledge regarding these electrolytes and the influence of their $\mu \mathrm{eq} / \mathrm{kg}$ on the metabolism of birds advanced, it was needful to account for them while calculating the electrolyte balance. Thus, the objective of this study was to assess the value of the best total electrolytic balance (BET) for the variables of performance and quality of the eggs in the laying hens.

\section{MATERIALS AND METHODS}

The experiment was conducted in the poultry nutrition laboratory of the Federal Institute of Northern Minas Gerais, in Januária, Minas Gerais. The proposed objectives wereachieved by adopting five diets, prepared to utilize the same electrolyte balance value $(200 \mu \mathrm{eq} / \mathrm{kg}$ ) proposed by MONGIN (1981), according to Equation 1.

Equation 1 : BE, $\mu$ eq $/ \mathrm{kg}$ of the feed $=(\mathrm{mg} / \mathrm{kg}$ of $\mathrm{Na}$ + of the feed / 22.990) $+(\mathrm{mg} / \mathrm{kg}$ of K + of the feed / $39.102)$ - (mg / kg of Cl- of the feed / 35.453).

Employing the equation proposed by ARAÚJO et al., (2011) the diets contained 1000, 1250, 1500, 1750, and $2000 \mu \mathrm{eq} / \mathrm{kg}$, respectively (Table 1).

Electrolyte balance equation according to ARAÚJO et al., (2011):

$\mathrm{BE}, \mu \mathrm{eq} / \mathrm{kg}$ da ração $=\left[\left(\mu \mathrm{eq} / \mathrm{kg}^{+} / \mathrm{kg}\right.\right.$ $\mathrm{Ca}^{2+}+\mu \mathrm{eq} / \mathrm{kg}^{+} / \mathrm{kg} \mathrm{K}^{+}+\mu \mathrm{eq} / \mathrm{kg}^{+} / \mathrm{kg} \mathrm{Na}^{+}+\mu \mathrm{eq} / \mathrm{kg}^{+} / \mathrm{kg}^{2}$ $\left.\mathrm{Mg}^{2+}\right)+\left(\mu \mathrm{eq} / \mathrm{kg}^{+} / \mathrm{kg} \mathrm{Lys}^{2}+\mu \mathrm{eq} / \mathrm{kg}^{+} / \mathrm{kg} \mathrm{Met}^{2}+\mu \mathrm{eq} / \mathrm{kg}^{+} /\right.$ $\mathrm{kg}$ Tre $+\mu \mathrm{eq} / \mathrm{kg}^{+} / \mathrm{kg} \operatorname{Trp}+\mu \mathrm{eq} / \mathrm{kg}^{+} / \mathrm{kg} \mathrm{Val}+\mu \mathrm{eq} / \mathrm{kg}^{+} /$

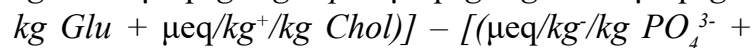
$\left.\mu \mathrm{eq} / \mathrm{kg}^{-} / \mathrm{kg} \mathrm{SO}_{4}^{-2}+\mu \mathrm{eq} / \mathrm{kg}^{-} / \mathrm{kg} \mathrm{Cl}^{-}+\mu \mathrm{eq} / \mathrm{kg}^{-} / \mathrm{kg} \mathrm{HCO}_{3}^{-}\right)$

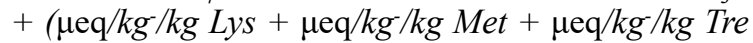

$+\mu \mathrm{eq} / \mathrm{kg}^{-} / \mathrm{kg} \mathrm{Trp}+\mu \mathrm{eq} / \mathrm{kg}^{-} / \mathrm{kg} \mathrm{Val}+\mu \mathrm{eq} / \mathrm{kg}^{-} / \mathrm{kg} \mathrm{Glu}+$

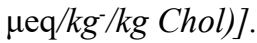

In this experiment, 240 laying hens of the Hy-Line Brown lineage in the 30- to 46-weeks-ofage class were used, with 4 periods of 28 days each, in completely randomized distribution design. Five treatments $(1000,1250,1500,1750$, and $2000 \mu \mathrm{eq} /$ $\mathrm{kg}$ ), were done in total, with eight replicates, using six birds in each experimental unit.

The laying hens were standardized based on weight and production and accommodated in a screened masonry shed covered with clay tiles $(5 \mathrm{~m}$ wide and $2 \mathrm{~m}$ in height), using galvanized wire cages with four $25 \times 45$ compartments. $\times 40 \mathrm{~cm}$, and were laterally distributed on two floors, $0.80 \mathrm{~m}$ above the floor level. A galvanized channel type of feeder and drinker were used, covering the entire front extension of the cages. Diets were calculated based on the levels reported by ROSTAGNO et al. (2011) (Table 1).

The birds were provided free access to feed and water and 17 hours of light per day throughout the experimental period, by the management recommendations of the lineage manual (MANUAL ISA POULTRY, 2010). The birds and the rations were weighed at the commencement and completion of the experimental period to confirm the weight gain, feed intake, feed conversion per dozen eggs, and egg mass.

The following characteristics were assessed: feed consumption (g / bird / day), egg production ( $\%$ / bird / day), egg weight $(\mathrm{kg})$, feed conversion per egg mass $(\mathrm{kg} / \mathrm{kg})$, feed conversion per dozen of eggs ( $\mathrm{kg} /$ dozen), final weight of birds ( $\mathrm{g}$ ) and uniformity (\%), Density (kg / L), Haugh Unit, Yolk (g), Albumin (g), Shell (g) and Total Egg Weight (g).

The specific gravity was determined by immersing the eggs in saline solutions of density

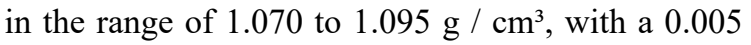
$\mathrm{g} / \mathrm{cm}^{3}$ interval, appropriately calibrated using a densimeter (OM-5565, Incoterm).

The weights of the yolk, albumen and shell were also determined, to accomplish which six eggs were randomly drawn from each repetition, from all the eggs collected over the last three days of each period. These were identified, weighed on a scale with $0.001 \mathrm{~g}$ accuracy. Then after breaking the egg, the shell was separated, washed, and dried in the open air for weighing at a later time.

The yolk was weighed immediately after breaking the egg, and the albumen weight was calculated as the difference between the total egg weight and yolk and shell weight. Statistical evaluation was then done using the analysis of variance and, when the significant effect was noted, 
Table 1 - Percentage and chemical compositions of experimental diets formulated according to ROSTAGNO et al., (2011) and their respective electrolyte balances.

\begin{tabular}{|c|c|c|c|c|c|}
\hline \multirow{2}{*}{ Ingredients (\%) } & \multicolumn{5}{|c|}{ 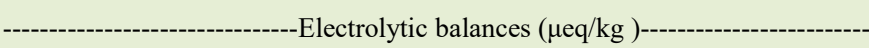 } \\
\hline & 1000 & 1250 & 1500 & 1750 & 2000 \\
\hline Corn & 56.502 & 56.486 & 56.461 & 56.428 & 57.028 \\
\hline Soybean meal & 23.475 & 23.470 & 23.470 & 23.480 & 22.100 \\
\hline Soybean oil & 4.455 & 4.460 & 4.470 & 4.480 & 4.335 \\
\hline Potassium carbonate & 1.200 & 1.200 & 1.200 & 1.200 & 1.358 \\
\hline Calcium bicarbonate & 1.945 & 1.495 & 1.040 & 0.588 & 0.127 \\
\hline Dicalcium phosphate & 2.760 & 2.750 & 2.750 & 2.750 & 2.768 \\
\hline Limestone & 8.430 & 8.905 & 9.370 & 9.840 & 10.310 \\
\hline Sodium chloride & 0.477 & 0.477 & 0.477 & 0.477 & 0.477 \\
\hline DL-Methionine 99\% & 0.268 & 0.268 & 0.268 & 0.268 & 0.282 \\
\hline L-Lysine $\mathrm{HCl}$ 99\% & 0.080 & 0.080 & 0.080 & 0.080 & 0.123 \\
\hline L-Threonine $98 \%$ & 0.074 & 0.075 & 0.075 & 0.075 & 0.750 \\
\hline L-Tryptophan & 0.014 & 0.014 & 0.014 & 0.014 & 0.022 \\
\hline Vitamin supplement 1 & 0.100 & 0.100 & 0.100 & 0.100 & 0.100 \\
\hline Mineral supplement 2 & 0.100 & 0.100 & 0.100 & 0.100 & 0.100 \\
\hline Choline chloride $60 \%$ & 0.100 & 0.100 & 0.100 & 0.100 & 0.100 \\
\hline Antioxidant3 & 0.020 & 0.020 & 0.020 & 0.020 & 0.020 \\
\hline \multicolumn{6}{|c|}{ 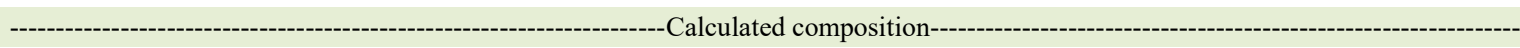 } \\
\hline Metabolizable energy, $\mathrm{kcal} / \mathrm{kg}$ & 2850 & 2850 & 2850 & 2850 & 2850 \\
\hline BE4, $\mu \mathrm{eq} / \mathrm{kg}$ (Mongin, 1981) & 250 & 250 & 250 & 250 & 250 \\
\hline $\mathrm{BE} 4, \mu \mathrm{eq} / \mathrm{kg}$ (Araújo, 2011) & 1000 & 1250 & 1500 & 1750 & 2000 \\
\hline Crude protein $(\%)$ & 15.603 & 15.601 & 15.601 & 15.600 & 15.604 \\
\hline Digestible lysine (\%) & 0.780 & 0.780 & 0.780 & 0.780 & 0.780 \\
\hline Digestible methionine (\%) & 0.490 & 0.490 & 0.490 & 0.490 & 0.496 \\
\hline Methionine + digestible cystine $(\%)$ & 0.710 & 0.710 & 0.710 & 0.710 & 0.710 \\
\hline Digestible threonine (\%) & 0.593 & 0.593 & 0.593 & 0.593 & 1.226 \\
\hline Digestible tryptophan (\%) & 0.179 & 0.179 & 0.179 & 0.179 & 0.179 \\
\hline Glycine+Total Serine (\%) & 1.384 & 1.383 & 1.384 & 1.384 & 1.330 \\
\hline Digestible valine (\%) & 0.651 & 0.651 & 0.651 & 0.651 & 0.626 \\
\hline Digestible isoleucine (\%) & 0.598 & 0.597 & 0.598 & 0.598 & 0.573 \\
\hline Arginine Dig (\%) & 0.955 & 0.954 & 0.954 & 0.955 & 0.913 \\
\hline Phenylalanine+ Digestible Tyrosine (\%) & 1.196 & 1.196 & 1.196 & 1.196 & 1.150 \\
\hline Digestible histitidine (\%) & 0.396 & 0.396 & 0.396 & 0.396 & 0.382 \\
\hline Linoleic acid (\%) & 1.337 & 1.337 & 1.336 & 1.335 & 1.343 \\
\hline Calcium $(\%)$ & 4.759 & 4.761 & 4.759 & 4.761 & 4.760 \\
\hline Match available (\%) & 0.601 & 0.599 & 0.599 & 0.599 & 0.600 \\
\hline Sodium $(\%)$ & 0.206 & 0.206 & 0.206 & 0.206 & 0.206 \\
\hline Crude fiber $(\%)$ & 2.647 & 2.643 & 2.643 & 2.642 & 2.630 \\
\hline Neutral detergent fibre $(\%)$ & 10.584 & 10.576 & 10.574 & 10.571 & 10.541 \\
\hline Acid detergent fibre (\%) & 4.450 & 4.445 & 4.444 & 4.443 & 4.422 \\
\hline
\end{tabular}

1Vitamin mixture (kg of product): vit. A - 10,000,000 I.U.; Vit. D3 - 2,000,000 I.U.; Vit. E - 30,000 U.I. A;vit. B1 - 2.0 g; Vit. B2 - 6.0 g; Vit. B6 - 4.0 g; Vit. B12 - 0.015 g; ace. pantothenic - 12.0 g; biotin - 0.1 g; Vit. K3 - 3.0 g;ác. Folic - 1.0 g; ace. Nicotinic - 50.0 g; If 250.0 mg. 2Mineral mixture (kg of the product): Fe - $80 \mathrm{~g}$; Cu - 10 g; Co - 2 g; Mn - 80 g; Zn - 50 g; I - 1 g. 3 Antioxidant: BHT (Butylhydroxy toluene). 4 Electrolytic Balance.

the regression equations were performed taking into account the electrolyte balance $(\mu \mathrm{eq} / \mathrm{kg}$ as a concomitant variable), through the PROC MIXED in the statistical program SAS (2001). Later, the
BET effects were tested using Dunnett's test at 5\% probability, by comparison of the control treatment with the others. The $\mathrm{R}^{2}$ value was achieved from the data noted in each of the experimental repetitions. 


\section{RESULTS AND DISCUSSION}

In this experiment, we observed the maximum and minimum temperature to be $32.7{ }^{\circ} \mathrm{C}$ and $19.4{ }^{\circ} \mathrm{C}$, on average, respectively, and the relative humidity on average, as $47.75 \%$. The variables of consumption, egg production, feed conversion per dozen eggs, the final weight of the birds remained unaffected $(\mathrm{P}>0.05)$ according to the experimental BET (Table 2).

CALDERON \& JENSEN (1990) reported no significant differences for the egg production of the laying hens fed on different quantities of protein in the feed. These results concur with the findings of MANJU et al., (2015) who, in their study on crude protein levels $(12,14,16,18 \%)$ and lysine content $(0.85$ and $1.0 \%)$, also discovered that the egg production, consumption of ration and egg quality remained unaffected.

The findings from this experiment correspond with those of some authors such as SILVA et al., (2006) who reported no difference in feed conversion per dozen eggs. In their studies, LAURENTIZ et al., (2005) recorded that the birds fed with $16.4 \%$ of $\mathrm{CP}$ showed improvement in the variables of feed conversion by dozen birds, egg production and weight of the eggs when the AAST levels were boosted from $0.45 \%$ to $0.60 \%$ in the diets for the Lohmann Brown hens in the second production cycle.

For the variable, the final weight of the birds, the BET treatment $1250 \mu \mathrm{eq} / \mathrm{kg}$, showed an improved result of $1678 \mathrm{~g}(\mathrm{P}>0.05)$, a value very close to that of the treatment using $1000 \mu \mathrm{eq} / \mathrm{kg}$. A BE value below $180 \mu \mathrm{eq} / \mathrm{kg}$ and above $300 \mu \mathrm{eq} / \mathrm{kg}$ lowers the weight of the birds (JOHNSON \& KARUNAJEEWA, 1985). HULAN et al., (1987) in their research on the effect of diets containing $\mathrm{Na}++\mathrm{K}+-\mathrm{Cl}$ - in different doses, revealed that the lowest and the highest weight gains were achieved with 174 and $215 \mu \mathrm{eq} / \mathrm{kg}$. Also, BORGES et al., (1999) observed that the best electrolyte balance was noted in concentrations of $199 \mu \mathrm{eq} / \mathrm{kg}$ and the $\mathrm{Na}+$ and $\mathrm{Cl}$ - ions.

The feed conversion per egg mass and uniformity values were influenced by the different BET values (Table 2, $\mathrm{P}<0.05$ ). For uniformity, birds given the BET treatment $1250 \mu \mathrm{eq} / \mathrm{kg}$, showed the best result. Therefore, for this parameter, the birds revealed an excellent electrolyte balance with $1250 \mu \mathrm{eq} /$ $\mathrm{kg}$, reiterating that they were more adapted to this relationship in the diet than with the other treatments.

The following equations were adjusted for the feed conversion by mass of the eggs (CAM), respectively: $\mathrm{CAM}=\left(-4.59 \times 10-7 \mathrm{BE}^{2}\right)+(0.0014$ $\mathrm{BE})+3.0815,(\mathrm{R} 2=0.47)$, achieving a $\mathrm{BET}$ value $=1525 \mu \mathrm{eq} / \mathrm{kg}$. However, these results differ from those recorded by LOPES et al., (2011) who found no significant effect for this parameter, in their study. By contrast, MORAES et al., (2019) reported a significant effect $(\mathrm{P}<0.05)$ concerning the electrolyte balance, indicating that the more quantity of $\mathrm{NaHCO} 3$ included in the diet the greater the feed conversion. These studies have considered only a small portion of the dietary electrolytes applying the classic BE calculation (MONGIN, 1981).

Regarding the variables of quality as shown in table 3: Colorimetric fan, density, Haugh unit, albumen weight, shell weight, and total egg weight, remained unaffected by the experimental BET.

The yolk weight alone was influenced by the different $\mathrm{BET}(\mathrm{P}<0.05)$. The birds that were given the BET treatment $1250 \mu \mathrm{eq} / \mathrm{kg}$, revealed better yolk weights, which indicates that this electrolytic balance with $1250 \mu \mathrm{eq} / \mathrm{kg}$ was more effective in this situation, with the objective being to raise the yolk

Table 2 - Performance of laying hens under different BET in diets.

\begin{tabular}{|c|c|c|c|c|c|c|c|c|}
\hline Variables & 1000 & 1250 & 1500 & 1750 & 2000 & SEM & $\mathrm{CV}$ & P-value \\
\hline Consumption (g/bird/day) & 116 & 111 & 111 & 114 & 111 & 2.55 & 0.045 & 0.172 \\
\hline Egg production (\%) & 84.7 & 84.9 & 82.3 & 85.1 & 81.66 & 21.72 & 0.051 & 0.369 \\
\hline Feed conversion per egg mass $(\mathrm{kg} / \mathrm{kg})$ & 2.19 & 2.06 & 2.10 & 2.09 & 2.19 & 0.026 & 0.016 & 0.022 \\
\hline Feed conversion per dozen eggs ( $\mathrm{kg} /$ dozen $)$ & 1.65 & 1.57 & 1.61 & 1.60 & 1.64 & 0.071 & 0.044 & 0.267 \\
\hline The final weight of birds $(\mathrm{g})$ & 1676 & 1678 & 1625 & 1657 & 1640 & 0.11 & 0.066 & 0.074 \\
\hline Uniformity $(\%)$ & 89.6 & 93.8 & 85.4 & 89.6 & 89.6 & - & - & - \\
\hline
\end{tabular}

$\mathrm{SEM}=$ Standard error mean; $\mathrm{CV}=$ Coefficient of Variation; $\mathrm{P}$-value= Probability Value; BET in $\mu$ eq $/ \mathrm{kg}=\mathrm{Total}$ Electrolyte Balance in $\mu \mathrm{eq} / \mathrm{kg} ;{ }^{*}$ Significant effect $(P<0.05)$. CA egg mass $=\left(-4.59 \times 10^{-7} \mathrm{BE}^{2}\right)+(0.0014 \mathrm{BE})+3.0815,\left(\mathrm{R}^{2}=0.47\right)$. 
Table 3 - Quality of eggs of laying hens under different BET in diets.

\begin{tabular}{|c|c|c|c|c|c|c|c|c|}
\hline Variables & 1000 & 1250 & 1500 & 1750 & 2000 & SEM & $\mathrm{CV}$ & P-value \\
\hline Colorimetric range (Roche) & 4.2 & 4.2 & 4.2 & 4.3 & 4.4 & 0.878 & 0.206 & 0.855 \\
\hline Density (kg/L) & 1.108 & 1.107 & 1.104 & 1.107 & 1.102 & 0.004 & 0.004 & 0.058 \\
\hline Haugh Unit & 129.7 & 128.8 & 130.4 & 129.8 & 130.1 & 1.19 & 0.009 & 0.071 \\
\hline Yolk (g) & 15.2 & 16.2 & 15.3 & 15.1 & 15.1 & 0.809 & 0.053 & 0.022 \\
\hline Albumin (g) & 36.8 & 38.2 & 38.5 & 38.8 & 38.2 & 1.74 & 0.046 & 0.211 \\
\hline Egg shell (g) & 5.7 & 5.9 & 5.7 & 5.7 & 5.5 & 0.338 & 0.059 & 0.265 \\
\hline Total egg weight (g) & 62.1 & 65.8 & 64.0 & 63.8 & 62.9 & 4.32 & 0.068 & 0.589 \\
\hline
\end{tabular}

$\mathrm{SEM}=$ Standard error mean; $\mathrm{CV}=$ Coefficient of Variation; $\mathrm{P}$-value $=$ Probability Value; BET in $\mu \mathrm{eq} / \mathrm{kg}=\mathrm{Total}$ Electrolyte Balance in $\mu \mathrm{eq} / \mathrm{kg}$;. ${ }^{*}$ Significant effect $(P<0.05)$. Yolk $=\left(1.10 \times 10^{-8} \mathrm{BE}^{3}\right)-\left(5.24 \times 10^{-5} \mathrm{BE}^{2}\right)+(0.078 \mathrm{BE})-21.73\left(\mathrm{R}^{2}=0.59\right)$.

weight, which ranks among the foremost features desired by the consumers.

Strikingly different from this study, LIMA et al., (2015) in their work using the sodium levels in quail diets to stabilize the electrolyte balance, concluded that the $0.10 ; 0.15,0.20,0.25$ and levels did not significantly affect ( $\mathrm{p}>0.05)$ egg performance and quality. JUNQUEIRA et al., while (2000) assessing the effects of the sources and levels of sodium, chlorine, and potassium, as well as the $(\mathrm{Na}+\mathrm{K}) / \mathrm{Cl}$ ratio, on the performance and characteristics of the hen laying blood plasma also reported no change ( $\mathrm{p}>$ $0.005)$ in the variables of the quality of eggs.

Regarding the yolk weight the equations mentioned were adjusted, Yolk $=\left(1.10 \times 10-8 \mathrm{BE}^{3}\right)$ - $\left(5.24 \times 10-5 \mathrm{BE}^{2}\right)+(0.078 \mathrm{BE})-21.73(\mathrm{R} 2=0.59)$. Achieving the values of BET $=1330 \mu \mathrm{eq} / \mathrm{kg}$ and BET $=2000 \mu \mathrm{eq} / \mathrm{kg}$ to attain maximum values of yolk weight are described by the cubic equation. However, the weight values of the buds estimated under BET = $1330 \mu \mathrm{eq} / \mathrm{kg}$ were even greater than those below BET $=2000 \mu \mathrm{eq} / \mathrm{kg}$.

With respect to the colorimetric range, the yolk pigmentation in the treatments revealed color intensities that were very close. In fact, OLIVEIRA et al., (2007) reported that the higher yolk pigmentation may have some connection to the inclusion of more corn in the diet because corn possesses natural xanthophylls that intensify the pigmentation. In terms of density, all the eggs were assessed in different $\mathrm{NaCl}$ solutions, and the treatment that attained the highest value was BET $1000 \mu \mathrm{eq} / \mathrm{kg}$, with a solution of $1.108 \mathrm{~kg} / \mathrm{L}(\mathrm{P}>0.05)$. In their studies, SILVA et al., (2006) reported that these data did not fall within the normal values for laying hens, which are in the range of 1.080 to $1.090 \mathrm{~g} / \mathrm{cm} 3$.
Regarding the Haugh unit, the BET 1500 $\mu$ eq / $\mathrm{kg}$ treatment produced numerically improved results $(\mathrm{P}>0.05)$. The result drawn from the Haugh Unit revealed excellent egg quality, as it exceeded the minimum value of 72 recommended by the EGG GRADING MANUAL (2000).

Considering albumen weight, BET 1750 $\mu$ eq / $\mathrm{kg}$ demonstrated a better numerical result $(\mathrm{P}>0.05)$ compared to the other treatments. These data corroborate those found by

No significant effect $(\mathrm{P}>0.05)$ was observed for the relative weight of the eggshell. By altering the prosthetic and amino acid levels of the diet, egg size can be changed to possibly minimize the problems of shell quality observed by the completion of the first and second production cycles. This occurred, most likely, because the quantity of shell deposited gets reduced at a level equal to or higher than the degree to which the albumen or yolk is reduced (PAVAN et al., 2005).

According to PINTO et al., (2002), egg weight is dependent upon the quality and quantity of protein consumed by the laying hens from their diet and can be a useful reference to guarantee their amino acid requirements. The high protein level and amino acid content of the diet remarkably influenced the egg size (ATTIA et al., 2020). In this study, the BET treatment $1250 \mu \mathrm{eq} / \mathrm{kg}$ enabled a good total egg weight $(\mathrm{P}>0.05)$ to be attained. A comparison was made of these results with those of MAKLED and CHARLES (1987) who reported that egg production remains unaffected when $\mathrm{NaHCO} 3$ is added to the diet.

These findings are exceptional from those found in the literature for the method of BE calculation used, according to ARAÚJO et al. (2011). In fact, MURAKAMI et al. (2006) in their evaluation using the classic BE method for the first and second 
cycles of the hen layers, reported ideal values of 205 $\mu \mathrm{eq} / \mathrm{kg}$, for the first production cycle, and $174 \mu \mathrm{eq} /$ $\mathrm{kg}$, for the second one. However, in this methodology, a much lower electrolyte volume than the one used in this study was evaluated.

\section{CONCLUSION}

The different BET values used were observed to affect the performance of the hens. The electrolyte balance values which gave the lowest possible feed conversion, improved yolk weight, and induced better uniformity were, respectively, BET = $1525, \mathrm{BET}=1330$ and $\mathrm{BET}=1250$ in $\mu \mathrm{eq} / \mathrm{kg}$ of the feed loads. From the regression equations, the BET value of 1390 was identified as ideal, for laying hens 30 to 46 weeks of age.

\section{BIOETHICS AND BIOSSECURITY COMMITTEE APPROVAL}

The project was submitted and approval was granted by the ethics committee for the use of animals (CEUA-IFNMG) under protocol 00124-2018.

\section{DECLARATION OF CONFLICT OF INTERESTS}

The authors declare no conflict of interest. The founding sponsors had no role in the design of the study; in the collection, analyses, or interpretation of data; in the writing of the manuscript, and in the decision to publish the results.

\section{ACKNOWLEDGEMENTS}

The authors are grateful for the support of Conselho Nacional de Desenvolvimento Científico e Tecnológico (CNPq) in the development of this work, through the granting of a research grant.

\section{AUTHORS' CONTRIBUTIONS}

All authors contributed equally for the conception and writing of the manuscript. All authors critically revised the manuscript and approved of the final version.

\section{REFERENCES}

ARAÚJO, W. A. G. et al. Cálculo de balanço eletrolítico em dietas de frangos de corte. Revista Eletrônica Nutritime, v.8, n.4, p.1529 - 1539, 2011. Available from: $<$ https:/www.nutritime.com. br/arquivos_internos/artigos/139V8N4P1529_1539_JUL2011_. pdf>. Accessed: Jul. 24, 2019.

ATTIA, Y. A. et al. Protein and Amino Acid Content in Four Brands of Commercial Table Eggs in Retail Markets in Relation to Human Requirements. Animals, v.10, n.3, p.406, 2020. Available from: $<$ https://www.mdpi.com/2076-2615/10/3/406>. Accessed: Jul. 24, 2019. doi: 10.3390/ani10030406
BORGES, S. A. et al. Fisiologia do estresse calórico e a utilização de eletrólitos em frangos de corte. Ciencia Rural, p.975-981, 2003. Available from: $<$ https://www.scielo.br/scielo.php?script=sci arttext\&pid=S0103-84782003000500028\&lang $=\mathrm{pt}>$. Accessed: Jul. 28, 2019. doi: 10.1590/S0103-84782003000500028.

CALDERON, VICTOR M.; JENSEN, LEO S. The requirement for sulfur amino acid by laying hens as influenced by the protein concentration. Poultry Science, v.69, n.6, p.934-944, 1990. Available from: <https://europepmc.org/article/med/2395789>. Accessed: Jul. 28, 2019. doi: 10.3382/ps.0690934.

EGG - Grading Manual. Washington: Department of Agriculture/ Agricultural Marketing Services. Agricultural Handbook, 75, 56p, 2000. Avalaible from: <https://www.ams.usda.gov/publications/ content/egg-grading-manual>. Accessed: May, 26, 2017.

HULAN, H. W. et al. Effect of altering the cation-anion $(\mathrm{Na}+\mathrm{K}-\mathrm{Cl})$ and calcium content of the diet on general performance and incidence of tibial dischondroplasia of broiler chickens housede in batteries. Nutrition Reports International, v.33, p.397-408, 1987.

JOHNSON, R. J.; KARUNAJEEWA, H. The effects of dietary minerals and electrolytes on the growt and physiology of the Young chick. Journal of Nutrition, v.115, p.1680-1690, 1985. Available from: <https://academic.oup.com/jn/article-abstract/115/12/1680/ 4763051?redirectedFrom=fulltext $>$. Accessed: Jul. 28, 2019. doi: $10.1093 / \mathrm{jn} / 115.12 .1680$.

LAURENTIZ, A. C. D. et al. Total sulfur amino acids levels for semi heavy weight laying hens after forced molt. Ciência Rural, Santa Maria, v.35, n.1, p.164-168, 2005. Available from: $<$ https://www.scielo.br/scielo.php?script=sci arttext\&pid=S0103$84782005000100026 \& \operatorname{lng}=p t \& t \operatorname{lng}=p t>$. Accessed: Apr. 29, 2019. doi: $10.1590 / \mathrm{S} 0103-84782005000100026$

JUNQUEIRA, O. M. et al. Efeitos das fontes e níveis de sódio, cloro e potássio e da relação $(\mathrm{Na}+\mathrm{K}) / \mathrm{Cl}$, sobre o desempenho e características do plasma sanguíneo de poedeiras comerciais. Revista Brasileira de Zootecnia. v.29, n.4, p.1110-1116, 2000. Available from: <https://www.scielo.br/scielo.php?script=sci artt ext\&pid=S1516-35982000000400023>. Accessed: Jul. 28, 2019. doi: $10.1590 / \mathrm{S} 1516-35982000000400023$.

LIMA, H. J. D. A. et al. Níveis de sódio na ração de codornas japonesas em postura. Revista Brasileira de Saúde e Produção Animal, v.16, n.1, 2015. Available from: <http://www.rbspa.ufba.br/ index.php/rbspa/article/view/2960/1649>. Accessed: Aug. 02, 2019.

LOPES, I. R. V. et al. Desempenho e qualidade dos ovos de poedeiras comerciais alimentadas com rações contendo farelo de coco tratado ou não com antioxidante. Revista Brasileira de Zootecnia, v.40, n.11, p.2431-2438, 2011. Available from: $<$ https://www.scielo.br/scielo.php?script=sci arttext\&pid=S151635982011001100021\&lng=pt\&tlng=pt $>$. Accessed: Aug. 03, 2019. doi: 10.1590/S1516-35982011001100021.

MAKLED, M. N.; CHARLES, O. W. Eggshell quality as influenced by sodium bicarbonate, calcium source, and photoperiod. Poultry science, v.66, n.4, p.705-712, 1987. Available from: <https:/www.sciencedirect.com/science/article/ pii/S0032579119526992?via\%3Dihub>. Accessed: Aug. 02, 2019. doi: $10.3382 /$ ps.0660705.

MANJU, G. U. et al. Effect of supplementation of lysine producing microbes vis-a-vis source and level of dietary protein 
on performance and egg quality characteristics of post-peak layers. Veterinary World, v.8, n.4, p.453, 2015. Available from: <http:// www.veterinaryworld.org/Vol.8/April-2015/4.html>. Accessed: Aug. 03, 2019. doi: 10.14202/vetworld.2015.453-460.

MANUAL ISA POULTRY. General management guide. Holanda, 2010, 41p. Available from: <http://www.isapoultry.com/ en/products/hisex/hisex-brown/>. Accessed: Mar. 15, 2018.

MONGIN, P. Recent advances in dietary anion-cation balance: application in poultry. Procedure Nutrition Society, v.40, p.285-294, 1981. Available from: <https://www.cambridge. org/core/journals/proceedings-of-the-nutrition-society/article/ recent-advances-in-dietary-anioncation-balance-applicationsin-poultry/C573362764A278489EEAB85CBECE2C25>. Accessed: Mar. 15, 2018. doi: https://doi.org/10.1079/ PNS19810045.

MORAES, M. T. T. et al. Effect of Different Dietary Electrolyte Balance Values at High Temperature Peaks on Performance and Egg Quality of Japanese Quail (Coturnix coturnix japonica). The Journal of Applied Poultry Research, v.28, n.4, p.1234-1239, 2019. Available from: <https://www.sciencedirect.com/science/ article/pii/S1056617119322883?via\%3Dihub $>$. Accessed: Mar. 15, 2018. doi: 10.3382/japr/pfz089.

MURAKAMI, A. E., SAKAMOTO, M. I., SOUZA, L. M. G. D., FRANCO, J. R. G., \& MITUO, M. A. O. Determinação do melhor nível de sal comum para codornas japonesas em postura. Revista Brasileira de Zootecnia, v.35, n.6, p.2333-2337, 2006. Available from: <https://www.scielo.br/scielo.php?script=sci arttext\&pid $=$ S1516-35982006000800019>. Accessed: Mar. 15, 2019. doi: 10.1590/S1516-35982006000800019.

OLIVEIRA MORENO, J. et al. Desempenho e qualidade dos ovos de poedeiras comerciais, alimentadas com dietas contendo sorgo e páprica em substituição ao milho. Acta Scientiarum. Animal Sciences, v.29, n.2, 2007. Available from: <http://periodicos.uem. br/ojs/index.php/ActaSciAnimSci/article/view/220>. Accessed Mar. 15, 2019. doi: 10.4025/actascianimsci.v29i2.220.
PATIENCE, J. F. A Review of the Role of Acid-Base Balance in Amino Acid Nutrition, Journal of Animal Science, n.68, p.398408. 1990. Available from: <https://academic.oup.com/jas/articleabstract $/ 68 / 2 / 398 / 4703994$ ?redirectedFrom=fulltext $>$. Accessed: Mar. 18, 2018. doi: 10.2527/1990.682398x.

PAVAN, A. C. et al. Níveis de proteína bruta e de aminoácidos sulfurados totais sobre o desempenho, a qualidade dos ovos e a excreção de nitrogênio de poedeiras de ovos marrons. Revista Brasileira de Zootecnia, v.34,n.2,p.568-574, 2005. Available from: $<$ https://www.scielo.br/scielo.php?script=sci arttext\&pid=S151635982005000200026\&lng=pt\&tlng=pt $>$. Accessed: Mar. 18, 2018. doi: $10.1590 / \mathrm{S} 1516-35982005000200026$.

PINTO, R. et al. Níveis de proteína e energia para codornas japonesas em postura. Revista Brasileira de Zootecnia, v.31, n.4, p.1761-1770, 2002. Available from: $<$ https://www.scielo.br/scielo.php?script $=$ sci arttext\&pid $=$ S1516-35982002000700019\&lng $=p t \& t \operatorname{lng}=\mathrm{pt}>$. Accessed: Mar. 18, 2018. doi: 10.1590/S1516-35982002000700019.

ROSTAGNO, H. S. et al. Tabelas brasileiras para aves e suínos: composição de alimentos e exigências nutricionais. 2.ed. Viçosa, MG: Universidade Federal de Viçosa, 2011. 252p.

SAS Institute. SAS/STAT procedure guide for personal computers. Version 5.ed. Cary, 1991.

SILVA, E. L. et al. Redução dos níveis proteicos e suplementação com metionina e lisina em rações para poedeiras leves. Revista Brasileira de Zootecnia, v.35, n.2, p.491-96, 2006. Available from: $<$ https://www.scielo.br/scielo.php?script=sci arttext\&pid=S1516$35982006000200022 \& \operatorname{lng}=$ pt\&tlng=pt $>$. Accessed: Mar. 20, 2018. doi: $10.1590 / \mathrm{S} 1516-35982006000200022$.

WANG, J. et al. Dietary chloride levels affect performance and eggshell quality of laying hens by substitution of sodium sulfate for sodium chloride. Poultry Science, v.99, n.2, p.966-973, 2020. Available from: <https://www.sciencedirect.com/science/article/ pii/S0032579119441898?via\%3Dihub>. Accessed: Mar. 20, 2018. doi: 10.1016/j.psj.2019.10.030. 